This item was submitted to Loughborough's Research Repository by the author.

Items in Figshare are protected by copyright, with all rights reserved, unless otherwise indicated.

\title{
Forging global networks in the imperial era: Atiya Fyzee in Edwardian
}

\section{London}

PLEASE CITE THE PUBLISHED VERSION

PUBLISHER

(C) Palgrave Macmillan; Individual chapters ( c contributors

VERSION

SMUR (Submitted Manuscript Under Review)

LICENCE

CC BY-NC-ND 4.0

\section{REPOSITORY RECORD}

Lambert-Hurley, Siobhan. 2019. "Forging Global Networks in the Imperial Era: Atiya Fyzee in Edwardian London". figshare. https://hdl.handle.net/2134/12376. 
This item was submitted to Loughborough's Institutional Repository (https://dspace.lboro.ac.uk/) by the author and is made available under the following Creative Commons Licence conditions.

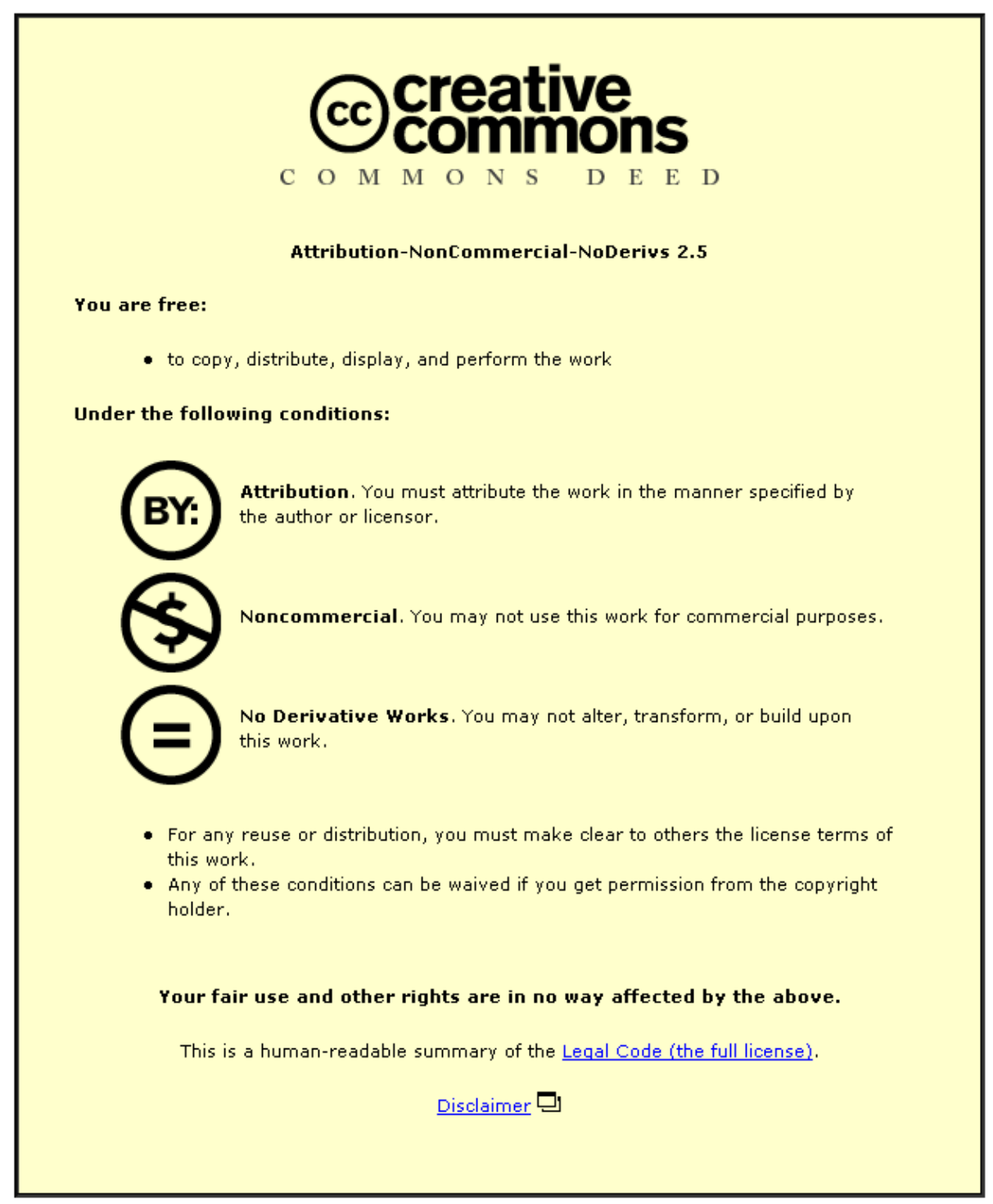

For the full text of this licence, please go to: http://creativecommons.org/licenses/by-nc-nd/2.5/ 


\title{
FORGING GLOBAL NETWORKS IN THE IMPERIAL ERA: ATIYA FYZEE IN EDWARDIAN LONDON ${ }^{1}$
}

\author{
Siobhan Lambert-Hurley \\ Department of Politics, History and International Relations \\ Loughborough University \\ Loughborough, Leicestershire \\ LE11 3TU \\ Email: S.T.Lambert-Hurley@lboro.ac.uk
}

This chapter examines the global networks forged by South Asians in Edwardian Britain through the eyes of Atiya Fyzee, a Muslim woman from Bombay. This era is perhaps the least well-served in the available literature on Indian travellers, students and settlers in Britain despite its frequent depiction as the apogee of British imperialism before the First World War began the process of decline. The financial and strategic resources demanded by the Boer War in South Africa and other overseas conflicts meant that imperial enthusiasm, already by this time, may not have been as whole-hearted as it had once been among the British public: 'frothy rather than deep-seated', in the judgement of one historian. ${ }^{2}$ And yet, Edwardian London remained a great imperial city at the heart of an equally great empire: no longer an industrial centre, but the nexus of the British Empire's political authority, financial power and commercial dominance over approximately one-quarter of the Earth’s population and one-quarter of its total land area. ${ }^{3}$ As such, London was meeting point for an impressive slice of humanity from across the globe: not just native Britons local to the city or visiting from the provinces, but also colonial subjects lured to the imperial 'centre' from British territories in Asia, Africa and the Americas. As one Indian traveller, A.L. Roy, wrote: 'London means the centre of a world-wide empire... a repository of wealth and a reservoir of energy... a whirlpool of activity and a deep sea of thought, a point where the ends of the world may be said to meet. ${ }^{4}$ Census figures for the period suggest that, at a time when 
Bombay, for instance, boasted less than a million people, the population of greater London was nearly seven million people, making it the largest imperial metropolis in the world. ${ }^{5}$

Of these millions, there were perhaps only a few hundred upper- or middle-class Indians living in, or visiting London by the Edwardian period - though literally thousands of ayahs and lascars, nursemaids and sailors, were coming into the country each year to fill gaps in the labour market. ${ }^{6}$ The still fairly limited South Asian population in Britain at this time means that the networks to be traced here were necessarily small. And yet, as Humayun Ansari emphasises in 'Making Transnational Connections', an essay focussing on interwar Muslim networks, these early formations had great significance. Not least, because they established 'patterns of interaction and community' around which later and larger South Asian communities in Britain were constructed. ${ }^{7}$ Like all networks, some of them operated within well-defined associational structures, while others were based on more informal relationships. Included in the latter category were a number of uneven 'cross-cultural collaborations' of the kind that Leela Gandhi has explored in the late Victorian context. In her book Affective Communities: Anti-Colonial, Fin-de-Siècle Radicalism and the Politics of Friendship, she uses the metaphor of friendship to examine how. when it came to antiimperialism, the sometimes over-simplified dichotomies between 'coloniser' and 'colonised' were reconfigured; by the complex networks that brought together, as an example, the socialist philosopher and early gay activist Edward Carpenter with the young Indian barrister and later nationalist M.K. Gandhi. ${ }^{8}$ Friendship, in other words, could at times prevail over the bounds of culture and imperialism, to enable a shared dissident politics to emerge.

This chapter will build on this approach by focusing on the travel diary, or roznamchah, of Atiya Fyzee (1877-1967), a young Muslim woman who spent the year of 1906-7 studying teachers' training at Maria Grey College in London. Examining the background to a number of specific individuals and the nature of the relationships they forged 
with Atiya at the time, it seeks to avoid as well as open up the parameters of the kind of reductive generalisations often applied to the diverse makeup of Britain's South Asian communities- especially, along lines of faith.

Atiya's script took the form of regular letters to her two sisters, Zehra and Nazli, which were edited for publication in serial form in the Urdu women's journal, Tahzib unniswan [Women's Culture], while she was abroad. ${ }^{9}$ In 1921, these entries also appeared in book form as Zamana-i-tahsil [A Time of Education]. ${ }^{10}$ Written in Urdu by a Muslim woman traveller, this particular source is rather different from those better-known travelogues by figures such as the Bombay Parsi journalist, JM Malabari’s in The Indian Eye on English Life (1893) that preceded or followed on. As Antoinette Burton has observed, those largely male, middle-class, English-educated travellers tended to peddle a 'commodified' Britain mapped in 'fairly formulaic terms' around London’s key attractions: 'Westminster Abbey, Saint Paul's, the Inns of Court, Buckingham Palace' interspersed perhaps with a sprinkling of English history. ${ }^{11}$ And as Elleke Boehmer intimates in her contribution to this volume many many such travelling Indians recognised a certain familiarity in London's modernity - a vision shared by Atiya as well. However, Atiya was bold enough to paint a far more informal and often irreverent picture of the people, places and activities that she encountered on a daily basis in London. ${ }^{12}$

A distinctive feature of Atiya's observations are her lively accounts of meetings with local elites and prominent Indians abroad - from former colonial officers and British gentry to renowned Muslim reformers and later nationalist leaders. Indeed, she mentions as many as 150 different individuals that she met over the course of her year in Britain. Why Atiya felt the need to 'name drop' in this way is not entirely clear, though it may say something of her uncertain social status. While she carried a certain standing as a member of the prominent Tyabji clan that was at the forefront of Bombay’s Sulaimani Bohra Muslim community, the 
Fyzee branch was comparatively lacking in money and rank. ${ }^{13}$ It was certainly less prominent than the group headed up by her famous great-uncle, Badruddin Tyabji (18441906), a figure often lionised in Indian history as a judge of the Bombay High Court and president of the Indian National Congress. ${ }^{14}$ Consequently then, many people that Atiya met in Britain knew her, not in her own right or even that of her immediate family, but through her wealthier and more established Tyabji cousins. ${ }^{15}$ Nevertheless, Atiya certainly distinguished herself as formative to an embryonic network of what Gail Minault has called 'secluded scholars', the earliest generation of Indian Muslim women to found modern girls' schools and contribute to Urdu women's journals. ${ }^{16}$ Like other memoirists of the time then-whether Indian or British-- Atiya may well have used her travelogue to catalogue people that she met or knew. In this way too, she may have sought to establish the intimacy of her social circle and to strategically boost her own sense of importance by emphasising connections with 'the great and the good'. ${ }^{17}$

Whatever her motives, Atiya's roznamchah is illuminating to the historian in offering a fascinating snapshot of the kind of personal, political and intellectual networks forged by South Asians in Edwardian Britain. In addition, the many and varied relationships depicted in this unique diary-- relationships which often cut across predictable class, gender and racial divides-- enable a more nuanced picture of how such networks were formed and overlapped in Britain's imperial capital. And yet a source such as Atiya's roznamchah is rarely employed in the service of imperial or global history. In part, its usage may have been limited by its inaccessibility in English translation. More serious, as Antoinette Burton has pointed out, is that many imperial historians have been tempted to dismiss personal narratives (especially those produced by women) as a 'subspecies of evidence' for their inability to pass the 'test of verifiability' ${ }^{18}$ What use can one woman's jottings be to a sub-discipline focused on grand transformation - as Linda Colley characterises the new world histories - in the form 
of 'ecological change', patterns of migration, 'networks of trade' and 'imperial systems'? ${ }^{19}$ Yet, by taking a biographical approach to an autobiographical source, we may actually begin to piece together the intricacies of those global networks, formal and not, that intersected in the great imperial city of London from the perspective of an often silenced or ignored historical subject: admittedly elite, but also female, Muslim and, as we have seen, by no means of the highest rank even within her own extended family. ${ }^{20}$ Revealed here too are the multiple and overlapping ways in which an Indian Muslim woman travelling to Britain could be an active participant in the creation of global networks formed on the basis of imperial connections; whether through kinship obligations, gender interests, religious identity, national affiliations or simply camaraderie. . ${ }^{21}$

So, who did Atiya Fyzee meet in Edwardian London? And what does her account of these meetings tell us about global networks, cross-cultural encounter and Edwardian society more generally?

In response to these questions, it is perhaps not surprising that most of Atiya's circle in London could be characterised - as was one acquaintance, Lady Scott, in her Times obituary - as having a 'liberal outlook on Eastern affairs' ${ }^{22}$ What this label implied in this period was rarely a desire to dismantle the British empire so much as an interest in reforming it - though, as Leela Gandhi notes, there was already a clique of Britons in fin-de-siècle London who were dedicated critics of empire. ${ }^{23}$ Reform was to be achieved by removing impediments to Indian advancement within the imperial system, lessening the racial barriers between British overlords and their Indian subjects, and encouraging greater investment on the part of the colonial state in education, healthcare, communications and economic infrastructure. While in Bombay during her husband's appointment as a high court judge, 
Lady Scott had arranged 'purdah parties' that brought together women of different racial and religious backgrounds, including, most likely, members of Atiya's own family. On her return to Britain, Lady Scott became known for her 'pro-Indian' letters to The Times, where she celebrated, to cite one example, the 'ready and kindly politeness' that had made her 'love India and the peoples of India' during her seven-year stay there. ${ }^{24}$ These sentiments point to the affinities possible between those who benefited from the 'privileges of imperialism' and the 'victims of their own expansionist cultures'. ${ }^{25}$ Even then at the heart of the imperial metropolis at the height of empire, the rigid oppositions between 'West' and 'non-West', coloniser and colonised, could be blurred.

Almost every other Briton Atiya met socially outside her college had spent time in India. Many had served as officers of the colonial state, either in an administrative or an army role, while others were the wife, daughter or sister of a colonial officer. ${ }^{26}$ Still others had visited India in some other employ, perhaps as educators, journalists or with a missionary organisation - a good example of the first being Thomas Arnold, who had been a professor at the Muhammadan Anglo-Oriental (M.A.-O.) College at Aligarh. ${ }^{27}$ That many of her contacts were a result of relationships already established in India through her prominent extended family is suggested, as in the case of the aforementioned Lady Scott, by some kind of Bombay connection. Indeed, a fair number had served in the Bombay civil service, while one, Lord Reay, was actually governor of the province. ${ }^{28}$ Though many of this group had spent the majority of their lives in India, Britain was always constructed in the imperial context as the 'home' to which they would inevitably return, whether on leave or in retirement. Yet return, was often accompanied by feelings of 'homelessness and alienation' that undermined their expected sense of belonging. ${ }^{29}$ One strategy to counter that dislocation may have been to seek out Indians in London, like Atiya, who were themselves trying to ease the unsettling experience of long-distance travel by making links to family in India. 
Much of the social interaction between those Britons-returned and those Indians visiting Britain, was facilitated in London by the National Indian Association (NIA). This organisation was founded in 1870 with the explicit aim of spreading knowledge of India in England and promoting education and social reform in India, fostering at the same time friendly relations between Indians and Britons. ${ }^{30}$ To this end, it took special responsibility for superintending young Indian students in Britain. Atiya, for instance, was received by two officers of this association upon her arrival in London and made a member of it soon after. ${ }^{31}$ Her descriptions of the various activities arranged by the NIA - including lectures and 'At Homes' at the Imperial Institute in Kensington, and outings to the Houses of Parliament point to this organisation's success in enabling easy racial mixing at the heart of empire in a way that would have been nigh on impossible in the Indian colony at this time. Little in evidence was the racial arrogance underpinning British imperialism from at least the midVictorian period that took form in colonial India's white-only clubs for European elites. ${ }^{32}$ The NIA thus represented 'a breach', to borrow a phrase of Leela Gandhi, 'in the fabric of imperial inhospitality. ${ }^{33}$ Consider, as an illustrative example, the 'At Home' that Atiya attended in March 1907. Having arrived with a Bengali fellow student and the English warden of her college residence, she met several of her own relatives, a number of English ladies, the daughter of a Bengali Anglophile, a former colonial officer and the Turkish ambassador. Together, they proceeded to poke fun at a decorated military hero, laugh surreptitiously at a celebrated singer, admire a recitation of Persian poetry, and discuss the loss of a gentlewoman's jewellery. ${ }^{34}$ Other meetings described by Atiya, proved to be as integrated and as lively, suggesting that this incident was far from unusual. ${ }^{35}$

Mixed private gatherings, too, were plentiful - so much so that Atiya often complained in her narrative of the frequency of invitations, many of which she turned down. ${ }^{36}$ Her sometimes ungrateful griping reflected, on one hand, Britain's thriving social 
scene in the Edwardian era. Led by a flamboyant, if not profligate King, Edward VII, the English aristocracy enjoyed lavish entertainments that allowed them to flaunt their considerable wealth - concentrated as it was in the hands of the very few - to the admiration of their equals and the awe of their subordinates. ${ }^{37}$ London's summer season in particular was characterised by a breathless round of parties, balls, dinners, teas and annual occasions a prominent example attended by Atiya being the Henley Royal Regatta. ${ }^{38}$ At the same time, Atiya’s apparent popularity may be attributed to how far the trope of 'the Indian woman' had captured the imagination of the British public. Simply put, everyone wanted to meet this 'exotic creature' that had been so publicised by journalists, like Mary Billington, in her series of articles in the Daily Graphic and later book, Women in India (1895). ${ }^{39}$ The nature of this kind of attention may also be attributable to Atiya's friend, Cornelia Sorabji - a barrister and social reformer from Bombay, whose significance is discussed in other chapters in this volume. It was Sorabji who had encouraged Atiya to apply for the scholarship to study in Britain in the first place and, who had also manipulated this notion of her Indian womanhood to foster her own celebrity when she studied at Oxford from $1889 .^{40}$ The ongoing interest of the press, heightened in the Edwardian period by the burgeoning women's movement, was apparent in Billington's application to Atiya for an interview almost immediately upon her arrival in London. It was soon followed by a request from the Lady's Pictorial, a respected women's magazine, for a picture and an article. ${ }^{41}$

It is perhaps not surprising that most of the Indians that Atiya encountered in Britain did not come from the majority working class community of ayahs or lascars, but instead were students, professionals, businessmen and nobility. Representative of the first two groups were many of her own relatives: her brother, Ali Azhar Beg, a doctor seeking to acquire a higher medical degree, her nephew, Tyab Ali Akbar, who eventually studied law, her cousin's husband, Camruddin Abdul Latif, who read languages at Cambridge before also 
turning to the law, and another cousin, Jabir Ali, who obtained a diploma in agriculture from Cambridge. Of these four, at least two did not return to India, but instead chose to settle in Britain where they became respected public figures. Camruddin took perhaps the more predictable route, being appointed a justice of the peace in London and playing an influential role in Indian and Muslim associations in Britain. ${ }^{42}$ Interestingly, he was also involved with the committee set up in 1911 to establish a mosque in London, a subject examined by Humayun Ansari in this volume. ${ }^{43}$ Ali Azhar, in contrast, made his mark as a tennis player, playing both at Wimbledon and in the Davis Cup during an impressive career that spanned three decades. ${ }^{44}$

Other members of Atiya's family that fit the category of student were her two female cousins, Naseema and Rafia. They were sent to England to study at an institution in Surrey in 1905, apparently because the quality of English language instruction in their school in Bombay was not deemed adequate by their reformist father, the great Badruddin Tyabji. ${ }^{45}$ These two young girls - aged around 20 and 16 during Atiya's visit - point to the not unusual phenomenon of Indian girls and women studying in Britain during the colonial era. In 1869, the highly-admired Bengali poetess, Toru Dutt, and her sister, Aru, had also been pioneers when they had attended 'Higher Lectures for Women' at Cambridge, after accompanying their broad-minded father, Govind Chunder Dutt, to Europe. ${ }^{46}$ Written less than four decades later, Atiya's narrative contains numerous references to Indian female scholars in Britain. As she observes when visiting University College in June 1907: 'Whichever educational institution I go to, I always find some or other Indian girl' ${ }^{47}$ Some were studying to be teachers alongside Atiya at Maria Grey College, while others were just young girls at school while their parents worked in Britain. Others followed in the footsteps of the Dutt sisters to Cambridge - a notable example being Janaki Bonnerjee, the daughter of celebrated Congress 
politician, Womesh Chunder Bonnerjee, who, when Atiya met her, was reading Natural Science, Chemistry, Zoology and Physiology at Newnham College. ${ }^{48}$

Many other Indians Atiya encountered in London were reformers who shared her passion for female education. An important example was Syed Ameer Ali. As she intimates in the travelogue, he was famed at the time for his legal and historical writing, his rulings as a high court judge in Calcutta, and his political activities as a Muslim loyalist - all of which made him probably the best known Indian Muslim in Britain in the Edwardian era. For Atiya though, it would have been his chapters on women's status in Islam in books like The Spirit of Islam (1891) that would have been of the greatest interest - for here he argued, like Sorabji, that Muslim women should be given their full legal rights as set out in the Qur'an. ${ }^{49}$ Appropriately, Atiya and Ameer Ali met on the occasion of a speech given by another Muslim modernist reformer, Abdullah Yusuf Ali, perhaps best remembered today for his English translation and commentary of the Qur'an, still in print. Talking about women in Islamic history, he highlighted the numbers of 'famous, able, intelligent and open-minded women' to distinguish themselves in the Muslim past. Like Ameer Ali in an earlier article, his examples included the thirteenth-century ruler of Delhi, Razia Sultana, the Mughal emperor Jahangir's capable wife, Nurjahan, the recently-deceased princely ruler, Shah Jahan Begam of Bhopal, and, to her consummate embarrassment, Atiya herself! ${ }^{50}$

The inclusion of this topic would not have been unexpected from a man who had spoken out in favour of female education in India at a number of public meetings during his two-year furlough in Britain from the Indian Civil Service. ${ }^{51}$ Yet this subject was also raised at events in London attended by Atiya and many others, whose names do not find their way into the recent histories of women's reform. A useful example was a lecture on 'The Effects of Western Education on Hindu Domestic Life', given by then Oxford student, Lala Har Dayal - later known for his anarchist politics, trade union activism and radical nationalism - 
at a meeting of the National Indian Association at the Imperial Institute. ${ }^{52}$ The discussion soon turned to female education when the first speaker, a Mr. Nathu Ram, declared that the education of girls would help break down the regrettable joint family system. His opinion was supported by a Mr. N. Pillai and a Mr. Charanjit Rai, the latter of whom declared that his daughter - though 'yet to be' - 'should not be imprisoned', but 'educated', so that she could become a 'pleasure instead of a burden to her parents'. ${ }^{53}$ Theodore Morison's lecture on Indian women's education at a meeting of the M.A.-O. College Association at Caxton Hall in January 2007, also brought Atiya together with other Indian advocates of female education not least a Mian Abdul Hamid from the princely state of Kapurthala, who described himself as a 'whole-hogger' in favour of women's 'education and independence'. ${ }^{54}$ This general interest suggests the continued importance of the 'woman question' to the Indian project of 'modernity' in the colonial context. From the early nineteenth century, women's status had been defined as a marker of 'civilisation' to the point that India's progress as a nation was understood to be dependent on women's advancement. Social reformers thus asked the question: 'how can women be modernised?' 55 No doubt the burgeoning suffragette movement in Britain at this time made this issue seem all the more critical.

On less formal occasions too, Atiya met other Indian enthusiasts for the cause of female education and emancipation, some of whom were women. The list of guests that she offered for the last NIA party she attended at the Imperial Institute in June 1907 is revealing in this connection in that it included, among others: Mrs Krishnabhabini Das, Mrs K.G. Gupta and Princess Sophia Duleep Singh. The first of these was a Bengali writer and reformer who, while her husband worked as a Cambridge lecturer, wrote travel pieces in Bengali and English in the Calcutta press. In these she commented, in particular, on the favourable position of women in Europe compared to the secluded existence of Bengali women. ${ }^{56}$ Shortly after her meeting with Atiya, she returned to India and devoted herself to 
promoting female education through the auspices of the Bengal branch of the first all-India women's organisation, the Bharat Stri Mahamandal. ${ }^{57}$ The wife of the first Hindu appointment to the Secretary of State's Council for India, Mrs. K.G. Gupta, was a Bengali known for her writing of a domestic manual entitled Pari Barick Jiban, and associated with the reformist Brahmo Samaj. ${ }^{58}$ This organisation had an established presence in Britain after the founder, Rammohun Roy - often celebrated as a 'champion of women's rights' on account of his sustained campaign to ban sati, or widow immolation - died in Bristol with Unitarian friends in $1833 .{ }^{59}$ Clearly then, relationships were already being forged in the imperial capital between women activists from opposite sides of the Indian subcontinent Bombay and Bengal - that would, in future, boost a national women's movement in India.

It was the last name on Atiya's list, however - Sophia Duleep Singh - who was to become the most celebrated figure in the history of the fight for equality and women's rights in Britain on account of her suffrage activities. Though Atiya never mentions it in her travelogue, her London sojourn took place just three years after the establishment of Britain's first organisation dedicated explicitly to women's political emancipation, the Women's Social and Political Union (WSPU), led by Emmeline Pankhurst and her two daughters, Christabel and Sylvia. They had high hopes that their demand for 'votes for women' would be met with the election of Sir Henry Campbell-Bannerman's government shortly before Atiya's arrival in London in 1906 - as it had been a promise of many Liberal candidates' manifestos. But, they were to be sorely disappointed. In response, this group of suffragettes, as they became known, launched a more militant campaign, not only giving lectures and holding rallies in the street - wholly unsuitable activities for 'respectable' women before this time - but also undertaking more violent forms of protest such as assaulting the police, breaking shop windows and threatening government ministers with horsewhips. ${ }^{60}$ A daughter of Maharaja Duleep Singh, the Sikh ruler of Punjab exiled after British annexation in 1849 
and who settled in Norfolk, Princess Sophia was involved directly with a number of high profile cases connected with the WSPU and the Women's Tax Resistance League. As a result, she was one of the many women arrested and fined in the years leading up to the First World War. ${ }^{61}$ Another of Atiya's female acquaintances, Mrs. P.L. Roy, was also a member of the WSPU, even serving on a committee that organised an Indian contingent for the women’s coronation procession in $1911 .^{62}$

Perhaps the best known students and professionals in Atiya’s acquaintance, however, were not family, women, reformers or feminists, but fellow Indian Muslims who were later to distinguish themselves as politicians or litterateurs. A prominent example of the former was Shaikh (later Sir) Abdul Qadir who, having made quite an impression on the NIA circle in London while a law student at Lincoln's Inn, went on to become a high profile politician in the Punjab. ${ }^{63}$ A second well-known case was Muhammad Iqbal. Whilst a student when Atiya met him in 1907, he was to become one of South Asia's most celebrated poets, writers, philosophers and politicians, still revered in Pakistan today as the Mussawir-i-Pakistan (or Architect of Pakistan). ${ }^{64}$ It was while completing research in Britain and Germany between 1905 and 1908 - and, in the process, becoming familiar with Western philosophy - that he began to develop his fresh and alternative perspective on Islam's modernity. ${ }^{65}$ A third in this triumvirate was Dr. Mukhtar Ahmed Ansari, who was a close friend of Atiya’s elder brother, Ali Azhar. At the time, Ansari was registrar of Lock Hospital in London, but, in 1910, he returned to India to launch a political career that saw him rise to the top of the Indian National Congress. ${ }^{66}$ In popular nationalist historiography, this trajectory has been attributed to Ansari having met a number of Congress leaders, including India’s first prime minister, Jawaharlal Nehru, and his father, Motilal, during his sojourn in England. ${ }^{67}$ Yet what is evidently clear from Atiya's narrative accounts of such meetings is that the personal and political networks formed by Indians in Britain were far more inclusive, drawing together 
figures of different political persuasions, whether loyalists, reformers, nationalists or separatists.

These examples - Qadir, Iqbal and Ansari, as well as the lascars, Tyabjis and social reformers already discussed - point to the existence of a thriving Muslim community in Britain in the Edwardian era of which Atiya was a part. The phenomenon of the 'British Muslim’ is still most commonly associated with Pakistani and Bangladeshi immigration after 1945. Yet, as Humayun Ansari has shown,the reach of the empire, combined with more informal commercial, political, and military links within the Islamic world saw growing numbers of Arabs, Turks, Malays, South Asians and others travelling to Britain by the nineteenth century to pursue political interests, education, and economic opportunities. Exact numbers are difficult to judge, but, on the basis of statistics kept on lascars and Indian students, it may be surmised that the Muslim community in Britain was made up of well over ten thousand people by the late Victorian period, some of whom would have been in transit, whilst others were more permanent settlers. ${ }^{68}$ Certainly, there were enough Muslims at any one time to sustain a mosque at Woking in Surrey from 1889 and Liverpool from 1891, though neither was visited by Atiya. She did, however, join with other Muslims at the Islamic Society on at least one occasion. Noting that this meeting was a 'large gathering' of 'Muslims wearing different costumes', her observation suggests that this organisation provided a cultural focus for an already diverse Muslim community in Britain. ${ }^{69}$

Significantly too the diasporic set to which Atiya belonged in London was surprisingly fluid in terms of class and creed. Whilst few records survive that detail the lives of the working-class ayahs and lascars, the educated middle-classes certainly mixed freely across India’s nouveau riche and feudal elite, whether Hindu, Muslim, Parsi, Christian, Jew or Sikh. Atiya's closest friend in London, for example, was her girlhood companion, Navajbai Tata, who, as her surname suggests, had married into the family of India's most 
successful Parsi industrialists. ${ }^{70}$ Another close friend was Flora Sassoon, of the wealthy Jewish family that ran the formerly Bombay-based trading company, David Sassoon \& Sons. Eager to renew their earlier acquaintance, this grand dame would send her motorcar to bring Atiya from her teachers' training college in Brondesbury to the family home in central London. ${ }^{71}$ There, Atiya was to meet several young women of another family of Indian Jews, the Ezras of Calcutta. She notes of them with customary succinctness, 'They are very wealthy people; which riches in the world can they not enjoy?' ${ }^{72}$ This comment could equally as easily been applied to the Indian royals she met in London. Riding on the reputation of her sister, Nazli, the Begam of Janjira, and her cousins, Abbas and Amina Tyabji - then resident in Baroda - she was entertained by or alongside a number of Indian princes, including the Maharaja and Maharani of Baroda. ${ }^{73}$ Though often responsible for sizeable kingdoms, these princes were just a few of the many who, to the consternation of their British overlords, spent increasing amounts of time in Europe from the late nineteenth century. ${ }^{74}$

Of course, most of Atiya's time in London would have been spent, not with old India hands, earnest reformers, 'brother' Muslims or glamorous Indian friends, but her fellow students and staff at the Maria Grey College. Among these women she appears to have made some genuine friends. Primary among them was Miss Catherine Firth, an 'intelligent girl' in her final term at the College who, having already obtained a University of London degree, went on to have an impressive career in education. ${ }^{75}$ Throughout the autumn, she accompanied Atiya on walks, visits and outings. The close personal nature of their relationship is suggested by Atiya's concern over her friend's performance in her December examinations and their exchange of books at Christmas. ${ }^{76}$ Other students Atiya befriended were Miss Malvina H. Green and Miss M.H. Goldsmith. As the first went on to become a missionary in China, it may be conjectured that they forged a relationship on the basis of a mutual interest in 'the East'. ${ }^{77}$ The latter Atiya purported to like 'very much' on the basis 
that she was 'very capable and artistic' - and, thus, it may be reasoned, was like Atiya herself. ${ }^{78}$ Atiya does not appear to have kept in touch with any of these girls after they left the college. But, in her ability to make friends with local English women, she was distinguished from her Indian male contemporaries. According to Shompa Lahiri, they had difficulty making informal contacts in Britain by the early twentieth century on the basis that they had come to be perceived by the 'British establishment' as a political and sexual threat. ${ }^{79}$ Yet for Atiya, friendship proved as much a factor in forging connections as imperial, national, religious, kinship and gender identities.

When Atiya Fyzee embarked on her first trip to Europe in 1906 aboard the P\&O steamboat, Moldavia, she was just one of 30 million other Indians to travel overseas between 1830 and $1930 .^{80}$ From the data available, it would appear that a fair number of travellers to Britain were Muslim women, whether bonded servants or elite Begams. ${ }^{81}$ To be a South Asian Muslim woman in Britain in the late Victorian or Edwardian period was not then in itself unique. However, where Atiya differed from many of her fellow travellers was in her decision to write about her experiences: to keep a travel diary, where, as we have seen, she recorded not only her everyday activities, but also her spirited meetings with a multitude of different individuals. Her diary thus offers a rare view into the early South Asian diaspora in Edwardian Britain as she reveals London's streets, clubs, restaurants, colleges, homes and gardens to be as much a 'contact zone' for cross-cultural encounter as her native Bombay.

So what does Atiya's personal autobiographical narrative suggest about Britain’s multicultural past, colonial South Asia and global networks during the period of empire? In common with some of the other essays published here, it challenges first of all the possibility of continuing to recount British history as a discrete 'island story', unconnected with empire or world history at large. Atiya's narrative implicitly questions the narrow focus of such 
orthodox accounts by providing a unique window into the complex relations of a British society already multicultural, multiracial and multireligious by the mid-Edwardian period, as well as the converging and divergent tendencies of the diasporic communities within it. Significantly, there are no simple generalisations we can extract from her narrative about 'South Asians in Britain’ or, perhaps more especially in light of contemporary political agendas, 'British Muslims’. Their personal, political and intellectual networks were clearly multifaceted, diverse and often unpredictable.. Importantly, too, there is a sense throughout that racial mixing was already possible within the imperial capital, even as it was still largely unfathomable in India itself. Furthermore, she draws out attention to the inclusivity of Muslim political networks in Britain, groups that were constituted of loyalists, reformers, nationalists and separatists, which again reflect the mixed nature of this early South Asian diaspora in London, whether in terms of occupation, class or creed. In addition, connections already established 'at home' in India were revived in the imperial 'centre' by new people, in new contexts, creating new configurations to forge global networks that sustained an imperial culture, even as they sought to undermine it.

\section{Endnotes}

1 This paper is an adapted and revised version of chapter three, 'Empire, Society, Diasporic Communities', in Siobhan Lambert-Hurley and Sunil Sharma, Atiya's Journeys: A Muslim Woman from Colonial Bombay to Edwardian Britain (Delhi: Oxford University Press, 2010). 2 T.O. Lloyd, Empire, Welfare State, Europe: History of the United Kingdom 1906-2001, 5th ed. (Oxford: Oxford University Press, 2002), p. 3.

3 For a picture of London at this time, see Jonathan Schneer, London 1900: The Imperial Metropolis (New Haven: Yale Nota Bene, 2001). 
4 A.L. Roy, Reminiscences English and American, Part II: England and India (Calcutta, 1890), quoted in Antoinette Burton, 'Making a Spectacle of Empire: Indian Travellers in Finde-Siècle London', History Workshop Journal 42 (1996): 128-9.

5 'London Metropolitan Area Population from 1891' [http://www.demographia.com/dmlonarea.htm, accessed 4 September 2008]; and H.H. Risley and E.A. Gait, Report on the Census of India, 1901 (Calcutta: Superintendent of Government Printing, 1901), p. 31.

6 Rozina Visram, Asians in Britain: 400 Years of History (London: Pluto Press, 2002), p. 45, 51-61.

7 Humayun Ansari, ‘Making Transnational Connections: Muslim Networks in Early Twentieth-Century Britain' in Islam in Inter-War Europe, ed. by Nathalie Clayer and Eric Germain (London: Hurst \& Company, 2008), p. 32.

8 Leela Gandhi, Affective Communities: Anticolonial Thought, Fin-de-Siècle Radicalism, and the Politics of Friendship (Durham NC: Duke University Press, 2006).

9 For examples of her original contributions to Tahzib un-niswan, see issues dated 26 January 1907-30 November 1907.

10 Atiya Fyzee, Zamana-i-tahsil (Agra: Matba‘ Mufid-i-‘Am, 1921). Quite recently, the text has also been republished in an Urdu journal from Islamabad: 'Atiya Faizi ki nadir khudnavisht “Zamana-ye tahsil”’, ed. by Muhammad Yamin 'Usman, Me’yar, 2, 1 (2009), pp. 103-86.

11 Antoinette Burton, At the Heart of the Empire: Indians and the Colonial Encounter in Late Victorian Britain (Delhi: Munshiram Manoharlal, 1998), pp. 46-7. Also see her ‘Making a Spectacle of Empire: Indian Travellers in Fin de Siecle London', History Workshop, 42 (Fall 1996), pp. 126-46.

12 For a discussion of Atiya's Zamana-i-Tahsil as a narration of the everyday, see Lambert- 
Hurley and Sharma, Atiya's Journeys, ch. 4.

13 On the Tyabji clan, see Theodore P. Wright, Jr's 'Muslim Kinship and Modernization: The Tyabji Clan of Bombay’ in Family, Kinship and Marriage among Muslims in India, ed. by Imtiaz Ahmad (Delhi: Manohar, 1976), pp. 217-38.

14 See, for instance, A.G. Noorani, Badruddin Tyabji (Builders of Modern India) (Delhi: Publications Division, Ministry of Information and Broadcasting, Government of India, 1969). It may be noted that Badruddin was not actually Atiya's uncle in the strict sense, but her mother's paternal uncle, or chacha.

15 Thanks to Professor C.M. Naim for emphasising this point on reading an earlier draft. 16 See Gail Minault, Secluded Scholars: Women's Education and Muslim Social Reform in Colonial India (Delhi: Oxford University Press, 1998), pp. 120, 185-7, 226, 234, 235, 240, 243, 289-9.

17 Thanks to Elleke Boehmer and Nick Hayes for directing me to examples of this trend. 18 Antoinette Burton, Dwelling in the Archive: Women Writing House, Home, and History in Late Colonial India (New Delhi: Oxford University Press, 2003), p. 139.

19 Linda Colley, The Ordeal of Elizabeth Marsh: A Woman in World History (London: Pantheon, 2007), pp. xxx-xxxi.

20 For a development of this point, see the concluding chapter on 'Travel, Biography, History' in Lambert-Hurley and Sharma, Atiya's Journeys, ch. 5.

21 For a discussion of Atiya's Zamana-i-Tahsil as a narration of the everyday, see LambertHurley and Sharma, Atiya's Journeys, ch. 4.

22 'Lady Scott', The Times, 13 May 1924, p. 16

23 Gandhi, Affective.

24 Leonora Scott, ‘To the Editor of The Times’, The Times, 3 March 1922, p. 8. 
25 Gandhi, Affective, p. 1.

26 For examples, see the biographical entries in Appendix 1 in Lambert-Hurley and Sharma, Atiya's Journeys.

27 On Arnold’s career, see H.A.R. Gibb, ‘Arnold, Sir Thomas Walker (1864-1930)’, Rev.

Christine Woodhead, Oxford Dictionary of National Biography (henceforth ODNB)

[http://www.oxforddnb.com/view/article/30457, accessed 23 June 2006].

28 On Lord Reay, see E.M. Satow, 'Mackay, Donald James, eleventh Lord Reay and Baron

Reay (1839-1921)', Rev. P.W.H. Brown, ODNB [http://www.oxforddnb.com/

view/article/34740, accessed 12 December 2006].

29 Georgina Gowans, 'Imperial Geographies of Home: Memsahibs and Miss-Sahibs in India and Britain, 1915-1947’, Cultural Geographies (2003), 424-41.

30 See the 1906 annual report of the National Indian Association, pp. 2, 6.

31 See Atiya's entries for 17 September and 1 October 1906, translated in Part II of LambertHurley and Sharma, Atiya's Journeys. All subsequent entries from her travelogue may also be consulted in this source.

32 On these clubs, see Mrinalini Sinha, 'Britishness, Clubbability, and the Colonial Public Sphere: The Genealogy of an Imperial Institution in Colonial India', Journal of British Studies, 40, 4 (2001), 489-521.

33 Gandhi, Affective, p. 189.

34 See Atiya’s entry for 4 March 1907.

35 See Atiya’s entries for 17 November 1906, 10 December 1906 and 28 May 1907.

36 See, for instance, Atiya’s entry for 28 September 1906.

37 Paul Thompson, The Edwardians: The Remaking of British Society, 2nd ed. (London: Routledge, 1992), p. 3-4. 
38 See Atiya’s entry for 4 July 1907.

39 On Mary Billington’s career, see ‘Miss Mary Billington’, The Times, 28 August 1925; and Fred Hunter, 'Billington, Mary Frances (1862-1925)', ODNB [http://www.oxforddnb.com/view/article/47609, accessed 23 June 2006].

40 See Burton, At the Heart of the Empire, ch. 3.

41 See Atiya's entries for 18 September and 26 September 1906. As Atiya notes in her entries for 1 December 1906 and 22 June 1907, her glamorous Indian friends, the Tatas and the Sassoons, were also often featured in local magazines.

42 For just a taste of his career, see 'Mahomedan Wedding in London', The Times, 4 August 1908; and ‘All-India Moslem League’, The Times, 7 June 1910.

43 ‘A Mosque for London’, The Times, 5 January 1911; and ‘The London Mosque’, The Times, 4 April 1911.

44 See reports on 'Lawn Tennis' in The Times, 1909-39. Safia Jabir Ali also refers to this illustrious sporting career in her entry for 5 October 1942 in her 'Manuscript Memoirs'. 45 Salima Tyabji, 'Creating an Identity: The Family Journals of Tyabjii Bhoymeeah of Bombay, 1877-1944’, unpublished manuscript.

46 Inderpal Grewal, Home and Harem: Nation, Gender, Empire, and the Cultures of Travel (London: Leicester University Press, 1996), p. 171. Also on women students in Britain, see Shompa Lahiri, Indians in Britain: Anglo-Indian Encounters, Race and Identity, 1880-1930 (London: Frank Cass Publishers, 2000), pp. 10-13.

47 See Atiya’s entry for 4 June 1907.

48 See Atiya’s entries for 4 March and 25 July 07; and Janaki Bonnerjee’s own description of her Newnham years in Family History, ed. by Antoinette Burton (New Delhi: Oxford University Press, 2003), p. 108. 
49 See Avril A. Powell, ‘Islamic Modernism and Women’s Status: The Influence of Syed Ameer Ali' in Rhetoric and Reality: Gender and the Colonial Experience in South Asia, ed. by Avril A. Powell and Siobhan Lambert-Hurley (New Delhi: Oxford University Press, 2003), pp. 282-317. On Sorabji, see chapters 2 and 7 in this volume.

50 See Atiya's second entry for 10 December 1906; and Ameer Ali, 'The Influence of Women in Islam', Nineteenth Century (May 1899), pp. 755-74.

51 See, for instance, Yusuf Ali's resolution proposed at the National India Association's annual general meeting for 1906 as reported in the organisation’s annual report, p 10.

52 On Lala Har Dayal, see Emily C. Brown, Har Dayal: Hindu Revolutionary and Rationalist (Tucson: The University of Arizona Press, 1975).

53 The discussion following Har Dayal's lecture was reported in The Indian Magazine and Review, no 433 (January 1907), pp. 15-17.

54 Mian Abdul Hamid’s comments were recorded in The Indian Magazine and Review, no. 435 (March 1907), p. 75

55 For a development of this point, see Geraldine Forbes, Women in Modern India (Cambridge: Cambridge University Press, 1996), pp. 12-14.

56 See Krishnabhabini Das, Englande Bangamahila, ed. by Simonti Sen (Calcutta: Stree, 1996).

57 Dagmar Engels, Beyond Purdah? Women in Bengal 1890-1939 (Delhi: Oxford University Press, 1996), p. 172.

58 On her career, see ‘Mrs K.G. Gupta’, The Times, 17 August 1908.

59 On Rammohun Roy in Britain, see Lynn Zastoupil, 'Defining Christians, Making Britons: Rammohun Roy and the Utilitarians’, Victorian Studies, 40, 2 (Winter 2002), 215-243. 60 For an accessible introduction to the history, see Harold L. Smith, The British Women's 
Suffrage Campaign, 1866-1928 (London: Longman, 1998).

61 Visram, Asians, pp. 165-8.

62 Ibid., p. 163.

63 On his career, see the biographical entry in Appendix 1 of Lambert-Hurley and Sharma, Atiya’s Journeys, p. 237.

64 On his career, see H.A.R. Gibb, ‘Iqbal, Sir Muhammad (1877-1938)’, rev. Francis

Robinson, ODNB [http://www.oxforddnb.com/view/article/34108, accessed 23 June 2006].

On his controversial relationship with Atiya, see Lambert-Hurley and Sharma, Atiya's

Journeys, ch. 2.

65 On the relationship between travel and modernity in Iqbal's thought, see Javed Majeed, Autobiography, Travel and Postnational Identity: Gandhi, Nehru and Iqbal (Basingstoke: Palgrave Macmillan, 2007), pp. 107-121.

66 On his career, see Mushirul Hasan, A Nationalist Conscience: M.A. Ansari, the Congress and the Raj (Delhi: Manohar, 1987).

67 See, for instance, his biography on the current Congress website [http://www.congresssandesh.com//AICC/history/presidents/dr_m_a_ansari.htm, accessed 16 January 2007].

68 These statistics, along with the history of Muslims in Britain that precedes them, are taken from Humayun Ansari, ‘The Infidel Within': Muslims in Britain since 1800 (London: Hurst, 2004), ch. 2.

69 See Atiya’s entries for 3 and 15 November 1906.

70 On Navajbai Tata and her husband, Ratan, see 'Death of Sir Ratan Tata. A Great Indian Figure', The Times, 7 September 1918.

71 See Atiya’s entry for 6 October 1906. 
72 See Atiya’s entry for 6 October 1906.

73 See Atiya’s entries for 14, 20, 27 October 1906 and 11 July 1907.

74 Barbara N. Ramusack, ‘Gaikwar, Sayaji Rao, maharaja of Baroda (1863-1939)’, ODNB [http://www.oxforddnb.com/view/article/30613, accessed 23 June 2006].

75 See Atiya’s entry for 4 December 1906; and Lilley, Maria Grey, p. 49.

76 See Atiya’s entries for 29 September, 13 October, 17, 24 and 29 November and 4, 10 and 26 December 1906.

77 See Atiya's entries for 15 October and 1 December 1906, 8 January 1907; and a letter from Miss Green detailing her experiences in China in The Maria Grey College Magazine, November 1910, pp. 2-3

78 See Atiya’s entry for 6 December 1906.

79 Lahiri, Indians in Britain, pp. 72-6.

80 See Sugata Bose, A Hundred Horizons: The Indian Ocean in the Age of Global Empire (Delhi: Permanent Black, 2006), p. 73.

81 Michael H. Fisher, Counterflows to Colonialism: Indian Travellers and Settlers in Britain 1600-1857 (Delhi: Permanent Black, 2004), pp. 222-4, 264-70, 411-22. 